\title{
Motivation - problems and prospects of research
}

\author{
T. L. Poliakova, V. V. Samarina
}

\author{
${ }^{1}$ Kharkiv Petro Vasylenko National Technical University of Agriculture \\ ${ }^{2}$ Kharkiv National Technical University "Kharkiv Polytechnic Institute" \\ Corresponding author. E-mail: tatyana_kharkov@outlook.com
}

Paper received 30.04.20; Accepted for publication 18.05.20.

\section{https://doi.org/10.31174/SEND-PP2020-229VIII93-09}

\begin{abstract}
The motivation of students for learning is the basis of any cognitive process. When it concerns the learning of foreign languages, the conscious approach of students to education and the individual approach of the teacher to the abilities of students are essential in creating positive associations of the student to the subject. Learning motivation is one of the decisive factors in the effectiveness of the learning process, and represents a complex of motives that cause students to be active in learning activities. Today foreign language teaching is defined by two important strategies: the development of communication skills and the use of online techniques. In fact, there is a process of rethinking the goals and objectives of education, and, therefore, the roles of the teacher and students. The student is not a passive recipient of the truth any longer, but a full participant of the process of cognizing it. This article describes the basic principles of motivation, as well as the tasks and principles of teaching, which are aimed at increasing students' motivation.
\end{abstract}

Keywords: motivation, learning, teaching, foreign language, interactive support.

Introduction. The shift from teaching perspective to learning perspective can be traced in the paradigm of the transition from behavioral to cognitive-constructivist educational assumptions. From a psychological point of view, the acceptance of works on interlingual learning [17], which focused on the learner, his previous experience, individual learning stages, and the processes and strategies associated with them, was a decisive factor for this new orientation. In process, the hitherto rather static, the concept of language intended as system-linguistic, was replaced by a productive and dynamic concept of language learning which gave a special emphasis to assessing a target language.

Theoretical background. This change in the didactic perspective - from the object of learning and teaching to the educational process and students - has been interpreted differently, with a particular emphasis in Europe on the development of a communicative approach and on the consideration of the student's needs from the point of view of the "addressee specificity". The consideration of the student's individual needs - also known as subjective needs [19, p. 96] - is reflected in the individualization approach, which is based on the knowledge of the student's individual variables [4]. Individualization is thought of as the desire to adapt the teaching method to the needs and interests of students. There are four forms of individualization: individualization of pacing, individualization of instructional goals, individualization of mode of learning und individualization of the learner's expectation [1]. In the Anglo-American region, the boundaries between individualization and the concept of autonomy are indistinct. Individualization functions as a collective concept encompassing various approaches to teaching and learning, from individualized learning to self-directed learning and autonomy. Tudor [19, p. 12] is fair to say that the actual goal of individualization found its adequate expression only in the concept of autonomy. Both perspectives require a new role for teachers and students (the teacher becomes a training instructor) and are focused on the need to "learn to teach" or "learn to learn to learn." This idea of active learning a foreign language is reflected, first of all, in the didactic discussion of student's autonomy, learning strategies and self-directed learning, which led to various studies.

Results and discussion. Motivation is undoubtedly one of the factors which is attributed both the greatest influence and the greatest potential for intervention (through motivating learning) by almost all teachers and didactics of foreign languages. The opinion that the (educational) motivation of students studying a foreign language can be improved by developing curricula (for example, by specially adapting curricula, contents and materials to students) has always been part of the didactics of a foreign language. Increasing motivation is seen as an opportunity to improve and accelerate learning outcomes.

Teaching models that take into account motivating students to learn a foreign language to the greatest possible extent but which are, at the same time, especially costly, are considered to be especially promising, since one cannot assume that motivation strategies are universally effective, as the motivational structure of each student is formed individually.

In the framework of a socio-educational model, which dominated until the 1990s and still occupies a prominent place [10], much attention is given to the relevance of students` (positive) attitude to L2, to the culture associated with it, as well as orientations focused on main motives and long-term goals of learning foreign languages. They distinguish between instrumental and integrative orientation in L2 learning. Instrumental orientation takes place if there is an assumption that the target language is useful for their later life (for example, to improve career opportunities), while integrative orientation arises from the interest and openness to foreign cultures - and especially to the target language culture, in relation to which a positive attitude prevails [11].

These two areas are not necessarily mutually exclusive; other specific directions such as travel motives, educational motives, and general contact motives have also been demonstrated $[5 ; 13]$.

As for German as a foreign language, various studies conducted in different countries, have shown that in addition to the specifics of the country and the region, general motivational trends which especially emphasize the instrumentality and the special status of mastering German 
(as an enrichment of a multilingual profile in addition to English proficiency) can also be observed [15].

The presented theoretical models suggest that good motivation combined with sufficient self-determination and an existing sense of success leads to motivated behavior. According to Gardner [10, p. 50], motivated learning has the following components: "a goal, effective behavior, a desire to achieve the goal and a favorable attitude to the activity under consideration." Thus, students should also have efforts (for example, studying vocabulary, solving problems related to a foreign language) which they have to make constantly, often for many years.

The models based on this approach describe the development of motivated actions as a process of converting goals and motivations into intentions for actions and, finally, into actions in which students have, for example, to choose between competing goals and cross the motivational threshold in order to actually initiate and support training actions $[7 ; 16]$. These motivational and volitional processes, occurring in students, are influenced by the appropriate sociocultural environment (for example, the influence of parents and peers), existing learning opportunities (for example, the use of the media). In case of controlled learning of a foreign language a significant influence is exerted by the teaching environment (the personality of the teacher, a group of students, study materials).

Students act on the basis of their individual expectations and goals; motivation is possible only if a student is clearly connected with his expectations, goals and needs. Motivation, therefore, involves an on-target selection of subjects, materials, media and teaching methods based on the interests and needs of the student. Another consequence of studying L2 motivation is the support of students in setting realistic learning goals (including intermediate goals) - especially in relation to German which is considered a specific language. It concerns the fact that, firstly, in the view of many regions German is believed to be especially difficult, and, secondly, it concerns learning German as a second language. Thus, accordingly, students need help to think over their educational progress. Longterm goals and success expectations should be regularly updated and maintained on the base of timely experience. Teachers should bring students to the experience of success, which they can ascribe to themselves and which they can control by themselves - in other words, they must strengthen students' self-confidence and their selfefficiency. In conditions where external motives predominate, students should be supported (especially in the context of compulsory schooling) to develop the forms of a more self-determining motivation for learning, including the perception that classroom and school subjects have real significance for their present and future life. Based on the measures that help students to better understand their own type of student and truly play out (and carefully expand) their repertoire of learning styles, these principles imply the teaching approach that favors student's autonomy through involving students in the process of making decisions on training issues and giving them real responsibility for their training [18].

In accordance with these rules, the teaching of German as a foreign language should take into account students previous experience and be connected with their motives for learning. Students should really be interested in topics, texts, and assignments which should be relevant to students. Students should be given the opportunity to apply the material they have already learned as often as possible (if possible, to use an authentic language in the target language environment) in order to get feedback on their (successful) individual learning status. Teachers should awake curiosity and interest, and not just assume them. They should also strengthen students' self-confidence through appropriate feedback and convince them that learning also implies social learning $[2 ; 8 ; 9 ; 21]$ also emphasize the core role of the teacher, his approach and his attitude to the motivational process. The most detailed proposal comes from Dörnyei [6], in which there are 35 (further divided) motivational strategies that include measures to: (a) create basic motivational conditions (for example, a favorable learning atmosphere, good group dynamics); (b) develop initial motivation; (c) maintain motivation during further learning (for example, motivating tasks, encouraging student autonomy); and (d) (positive) self-esteem of students (for example, strengthening motivational attributes, adapted feedback procedures).

Teachers must meet two basic requirements in a problem-oriented approach: "motivate students to complete tasks" and "provide interactive support for the tasksolving process" [20, p. 175]. Student motivation to work at the assignment means that "they are seen as active participants in the learning process" [14, p. 221]. In this context, teachers don't assume a role of mediators in the spread of knowledge, but, first of all, of mentors in the learning process. Teachers support students in the process of interpretation and implementation of the assignment and, thus, contribute to the educational progress.

The motivation for completing a task can depend on many factors. One of the most important criteria is the relevance of the proposed tasks in terms of their relevance to everyday life. Teachers should create a safe and supportive learning environment in which they can take an active part in a foreign language, participate in solving a complex problem where they can use their linguistic resources [12, p. 328]. To do this, the teacher should be able to interact with students, even if they deviate from the assignment planned [14, p. 222]. Positive regular feedback from the teacher helps to maintain students 'motivation until the assignment is completed. This engagement of students tends to lead to a greater orientation toward the goal and, therefore, to greater progress in studies [14, p. 222]. Requests for assignments and support offers are constantly being adapted to specific study groups and their specific character. Therefore, the task is always understood only as an initial offer to students, which is adapted in the learning process according to their needs and wishes [12, p. 328].

The second task of the teacher - "interactive support for the process of completing the task" - concerns mainly organization of the right conditions for mastering the language. This includes negotiations and understanding the content, ability to use the language and language structures. These aspects should be taken into account even when preparing and developing tasks in order to purposefully stimulate the process of learning a language by setting objectives. However, the task as a work plan that takes into account all these aspects, may differ from the actual task, so that in the end there will be no negotia- 
tions on the meaning, language production or awareness of language structures. In this case, the teacher's function is to help students overcome the cognitive and language barriers they encounter in the course of task fulfillment [14, p. 222]. Accordingly, teachers should more actively engage their students in the choice of content, goals, objectives, and learning mechanisms. The tasks that are clear and easily understood, challenge students and contribute to their personal development, not their boredom [3, p. 22].

Conclusion. Measures to motivate students can only be planned to a very limited extent, especially in relation to the prognosis of consequences and side effects. The motivation-action model has already made it clear that a motivational measure for a group always involves different abilities, attitudes and skills of the learners, implies incalculable (self-)assessments that allow the motivational potential to be or not to be realised in different ways: simple if-then relationships cannot be created. The success of motivational measures is, therefore, ultimately a reflection of successful classroom interaction and group dynamics.

\section{REFERENCES}

1. Altman, H. B. (1977): Individualized foreign language instruction and systems thinking: symbiosis and synergism. System 5/2, P. 76-83.

2. Apelt, Walter (1996) Motivation und Fremdsprachenunterricht - Bilanz und Ausblick. Fremdsprachenunterricht 40: S. 8189, 166-171.

3. Biebighäuser, Katrin / Zibelius, Marja / Schmidt, Torben (2012): Aufgaben 2.0 - Aufgabenorientierung beim Fremdsprachenlernen mit digitalen Medien. In: Dies. (Hg.): Aufgaben 2.0.: Konzepte, Materialien und Methoden für das Fremdsprachenlehren und -lernen mit digitalen Medien. Tübingen: Narr, S. 11-57.

4. Chastain, K. (1975): An examination of the basis assumptions of ,individualized' instruction. The Modern Language Journal 59/7, P. 334-344.

5. Cle'ment, Richard and Bastian G. Kruidenier (1983) Orientations in second language acquisition: I. The effects of ethnicity, milieu, and target language on their emergence. Language Learning 33: P. 273-291.

6. Dörnyei, Zolta'n (2001) Motivational Strategies in the Language Classroom. Cambridge: Cambridge University Press.

7. Dörnyei, Zolta'n and Istva'n Otto' (1998) Motivation in action: a process model of L2 motivation. Working Papers in Applied Linguistics 4: P. 43-69.

8. Dörnyei, Zolta'n and Kata Csize'r (1998) Ten commandments for motivating language learners: results of an empirical study. Language Teaching Research 2: P. 203-229.

9. Düwell, Henning (1998) Motivation und Motivierung im Fremdsprachenunterricht. In: Udo O. H. Jung (Hg.), Praktische Handreichung für Fremdsprachenlehrer, S. 38-46. 2., verbesserte und erweiterte Auflage. Frankfurt a. M. etc.: Lang.

10. Gardner, Robert C. (1985) Social Psychology and Second Language Acquisition. The Role of Attitudes and Motivation. London: Arnold.

11. Martinez Helene (2016): Lernerperspektive und Lernerorientierung. Handbuch Fremdsprachenunterricht 6., völlig überarbeitete und erweiterte Auflage A. Francke, S. 241-247

12. Müller-Hartmann, Andreas / Schocker, Marita (2016): Aufgabenorientierung. In: Burwitz-Melzer, Eva / Mehlhorn, Grit / Riemer, Claudia / Bausch, Karl-Richard / Krumm, HansJürgen (Hg.): Handbuch Fremdsprachenunterricht. 6., völlig überarbeitete und erweiterte Auflage. Tübingen: Francke, S. 325-329.
13. Noels, Kimberly A., Luc G. Pelletier, Richard Cle'ment and Robert J. Vallerand (2000) Why are you learning a second language? Motivational orientations and self-determination theory. Language Learning 50: P. 57-85.

14. Raith, Thomas (2010): Kompetenzen fördern statt nur zu fordern - Entwicklung aufgabenorientierter Kompetenzen bei Fremdsprachenlehrkräften im Vorbereitungsdienst. In: Altmayer, Claus / Mehlhorn, Grit / Neveling, Christiane / Schlüter, Norbert / Schramm, Karen (Hg.): Grenzen überschreiten: sprachlich - fachlich - kulturell. Dokumentation zum 23. Kongress für Fremdsprachendidaktik der Deutschen Gesellschaft für Fremdsprachenforschung (DGFF) Leipzig, 30. September - 3. Oktober 2009. Hohengehren: Schneider. (Beiträge zur Fremdsprachenforschung, 11), S. 219-231.

15. Riemer, Claudia (2006a) DaF-Lernende - alles Exoten? Motivationsforschung und Deutsch als Fremdsprache. In: Hans-Jürgen Krumm und Paul Portmann-Tselikas (Hg.), Innovationen - neue Wege im Deutschunterricht. Innsbruck: StudienVerlag (Theorie und Praxis. Österreichische Beiträge zu Deutsch als Fremdsprache Bd. 9/2005), S. 43-58.

16. Riemer, Claudia (2006b) Der Faktor Motivation in der empirischen Fremdsprachenforschung. In: Almut Küppersund Jürgen Quetz (Hg.), Motivation Revisited, Berlin: LIT-Verlag, S. 35-48.

17. Selinker, L. (1972): Interlanguage. International Review of Applied Linguistics 10/3, P. 209-231.

18. Solmecke, Gert (1983) Ein Motivationshandlungs-Modell für den Fremdsprachenunterricht. In: Gert Solmecke (Hg.), Motivation und Motivieren im Fremdsprachenunterricht, Paderborn: Schöningh. S. 271-278.

19. Tudor, I. (1996): Learner-centredness as language education. Cambridge.

20. Van den Branden, Kris (2006): Introduction: Task-based language teaching in a nutshell. In: Ders. (Hg.): Task-based language education: From theory to practice. Cambridge: Cambridge University Press, S. 1-16.

21. Wicke, Rainer E. (2004) Aktiv und kreativ lernen. Projektorientierte Spracharbeit im Unterricht Deutsch als Fremdsprache. Ismaning: Hueber.

22. Williams, Marion, Robert L. Burden and Safiya Al-Baharna (2001) Making sense of success and failure: the role of the individual in motivation theory“. In: Zolta'n Dörnyei and Richard W. Schmidt (Hg.), Motivation and Second Language Acquisition. University of Hawaiı.. Second Language Teaching \& Curriculum Center. P. 171-184. 